\title{
Use of laser capture microdissection allows detection of loss of heterozygosity in chromosome 9p in breast cancer
}

\author{
MARGARIDA FIGUEIREDO DIAS ${ }^{1}$, ROBERT BLUMENSTEIN $^{2}$ and JOSE RUSSO $^{3}$ \\ ${ }^{1}$ Departamento de Ginecologia, Centro Hospitalar da Universidade de Coimbra, \\ Coimbra 3000-375, Portugal; ${ }^{2}$ DeSales University, Allentown, Center Valley, PA 18034; \\ ${ }^{3}$ Breast Cancer Research Laboratory, Fox Chase Cancer Center, Philadelphia, PA 19111, USA
}

Received September 26, 2016; Accepted February 3, 2017

DOI: $10.3892 / \mathrm{ol} .2017 .5892$

\begin{abstract}
The present study was designed to determine whether loss of heterozygosity $(\mathrm{LOH})$ in the $\mathrm{p}$ arm of chromosome 9 in invasive ductal carcinoma of the breast is detected during the neoplastic progression of the disease. Using laser capture microdissection (LCM) epithelial cells were isolated from 14 invasive ductal carcinoma cases (IDC), ductal carcinomas in situ (DCIS), normal mammary lobules, skin and/or lymph nodes of paraffin embedded tissue sections. $\mathrm{LOH}$ analysis of chromosome 9p was performed utilizing the microsatellite markers D9S199, D9S157, D9S171, D9S265 and D9S270. The highest frequency of LOH was observed in invasive ductal carcinomas, which reached a maximum at the 9p22-23 chromosomal location (D9S157). In addition, DCIS lesions presented a high frequency of LOH in 9p22-23 (D9S157), followed by 9p21 (D9S171), D9S199 and D9S265, which were similar in frequency to those observed in IDC. A novel finding was the intralesional heterogeneity in $\mathrm{LOH}$ within the same DCIS or IDC case. This is an indication that clones of cells that differ in genetic composition coexist in the same lesion. Notably, phenotypically normal breast tissues adjacent to IDC or DCIS exhibited LOH at D9S157 and/or D9S171. Together, these data indicate that $\mathrm{LOH}$ of chromosome arm 9p occurs very early in the progression of cancer and that different clones of cells co-exist within a single tumor.
\end{abstract}

\section{Introduction}

Human cancer arises through the accumulation of genetic alterations in multiple oncogenes and tumor suppressor genes. However, the exact timing of the majority of molecular genetic events during carcinogenesis and their correlation with defined

Correspondence to: Dr Margarida Figueiredo Dias, Departamento de Ginecologia, Centro Hospitalar da Universidade de Coimbra, Praceta Mota Pinto, Coimbra 3000-375, Portugal

E-mail: marg.fig.dias@gmail.com

Key words: breast cancer, laser microdissection, chromosome 9p, loss of heterozygosity, genetic heterogeneity histopathological stages are largely unknown. (1-7). Invasive ductal carcinoma (IDC) of the breast is the result of a multistep process, beginning with ductal hyperplasia and followed by atypical ductal hyperplasia, ductal carcinoma in situ (DCIS), invasive ductal carcinoma and metastatic disease (1-3). Previous studies in the literature (8-10) indicate that alterations in the $\mathrm{p}$ arm of chromosome 9 may be a common denominator in human cancer, and may have a role in the early stages of breast cancer, including ductal hyperplasia and DCIS (11-14). Of interest is the finding that loss of heterozygosity $(\mathrm{LOH})$ in the $\mathrm{p}$ arm of chromosome 9 may be involved in the pathogenesis of breast cancer (15-19).

In the present study, laser capture microdissection (LCM) was used to analyze paraffin-embedded tissues of the normal breast, ductal hyperplasia, DCIS and IDC to obtain DNA from selected populations of cells for molecular genetic analysis (20-22). LCM was used in order to obtain cells with a high degree of purity in their phenotypes, without contamination of stromal, inflammatory or other cells that could interfere with final conclusions of molecular analysis. The isolated cells representing different stages of breast cancer progression were used for detecting $\mathrm{LOH}$ using five microsatellite markers: D9S199, D9S 157, D9S 171, D9S265 and D9S270. The present study was conducted in an attempt to investigate the intratumoral heterogeneity and to associate chromosomal alterations with morphologic findings and proliferation state of the tumor.

\section{Materials and methods}

Tissue samples. Paraffin blocks from fourteen primary breast IDC cases (mean age, 56; range, 27-86) that also contained areas of carcinoma in situ were selected for the present study. Paraffin blocks containing areas of normal tissue, including breast, skin and lymph nodes, were available from the same patients. Tissue blocks were obtained from the tumor bank of the Breast Cancer Research Laboratory of the Fox Chase Cancer Center (FCCC; Philadelphia, PA, USA). Six serial $5-\mu \mathrm{m}$ sections were obtained from each paraffin-embedded tissue block and stained with hematoxylin and eosin (H\&E). The first section was coverslipped and the remaining five sections were dehydrated and air dried for their use in LCM and DNA extraction. Tissue sections containing IDC were selected on the basis that DCIS was also present in the same 


\begin{tabular}{|c|c|c|c|c|c|c|}
\hline \multirow[b]{2}{*}{24} & & $z$ & 亏 & 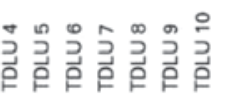 & 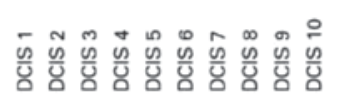 & 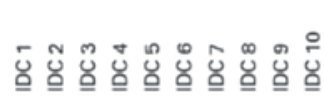 \\
\hline & D9S199 & $\begin{array}{r}1 \\
3 \\
3 \\
4 \\
5 \\
6 \\
8 \\
9 \\
10 \\
11 \\
12 \\
13 \\
14 \\
15 \\
16 \\
17 \\
20 \\
21 \\
22\end{array}$ & $\begin{array}{lllll}0 & 0 & 0 & c \\
0 & 0 & 0 & c \\
0 & 0 & 0 & 1 \\
0 & 0 & 0 & c \\
0 & 0 & 0 & c \\
0 & 0 & 0 & c \\
0 & 0 & 0 & c \\
0 & 0 & 0 & c \\
0 & 0 & 0 & c \\
0 & 0 & 0 & c \\
0 & 0 & 0 & c \\
0 & 0 & 0 & c \\
0 & - & 0 & c \\
0 & 0 & 0 & c \\
0 & 0 & 0 & c \\
0 & 0 & 0 & c \\
0 & 0 & 0 & c \\
0 & 0 & 0 & c\end{array}$ & $\begin{array}{llll}0 & & \\
0 & & \\
0 & & \\
0 & & \\
0 & & \\
0 & 0 & - & 0 \\
0 & 0 & 0 \\
0 & 0 & \\
0 & & \\
0 & 0 & \\
0 & & \\
0 & & \\
0 & & \\
0 & & \end{array}$ & 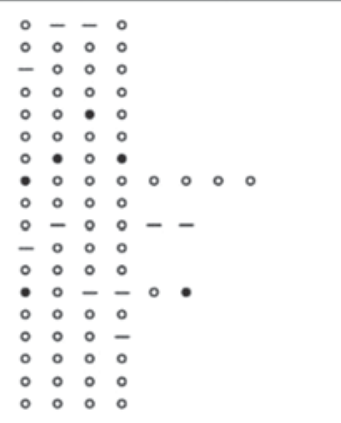 & 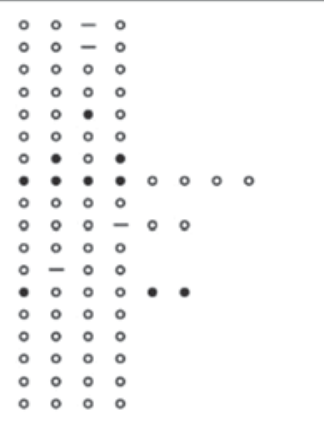 \\
\hline 23 & $\begin{array}{l}23 \mathrm{cM} \\
\mathrm{D} 9 \mathrm{~S} 157 \\
11 \mathrm{cM}\end{array}$ & $\begin{array}{r}1 \\
3 \\
4 \\
5 \\
5 \\
6 \\
8 \\
9 \\
9 \\
10 \\
11 \\
12 \\
13 \\
14 \\
15 \\
16 \\
17 \\
20 \\
21 \\
22\end{array}$ & 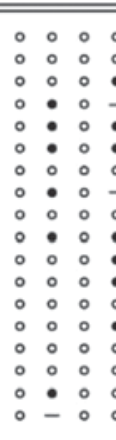 & 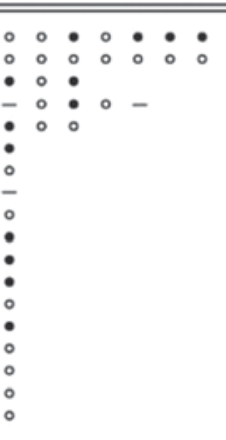 & 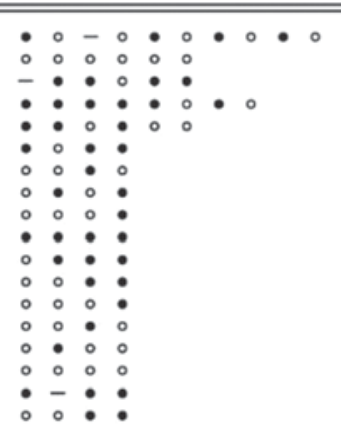 & 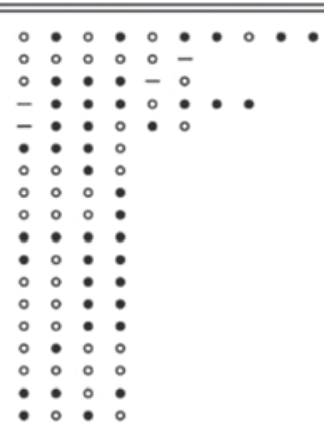 \\
\hline \multirow[t]{3}{*}{21} & $\begin{array}{l}\downarrow \\
\text { D9S171 } \\
\uparrow 1 \mathrm{cM} \\
\text { D9S265 } \\
\uparrow \\
9 \mathrm{cM}\end{array}$ & $\begin{array}{r}1 \\
3 \\
4 \\
5 \\
6 \\
8 \\
8 \\
9 \\
10 \\
11 \\
12 \\
13 \\
14 \\
15 \\
16 \\
17 \\
20 \\
21 \\
22\end{array}$ & 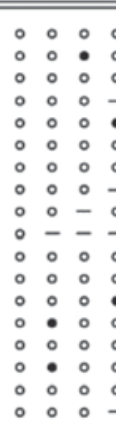 & 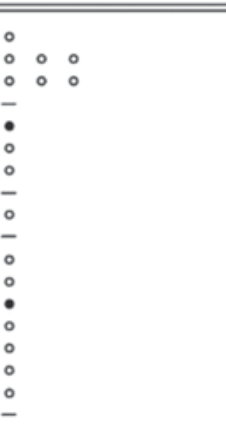 & 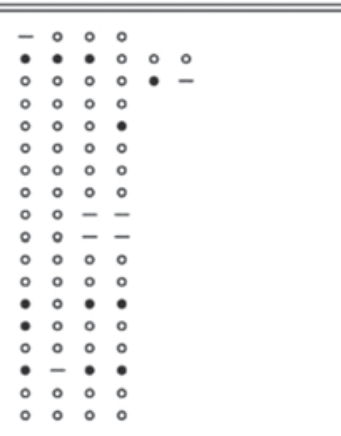 & 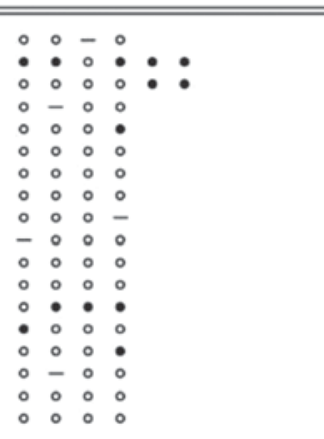 \\
\hline & $\begin{array}{l}\downarrow \\
\text { D9S270 }\end{array}$ & $\begin{array}{r}1 \\
3 \\
3 \\
4 \\
5 \\
6 \\
8 \\
9 \\
9 \\
10 \\
11 \\
12 \\
13 \\
14 \\
15 \\
16 \\
17 \\
20 \\
21 \\
22 \\
\end{array}$ & 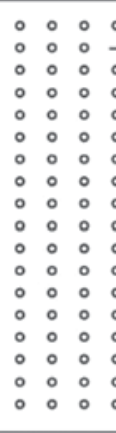 & $\begin{array}{l} \\
\\
0 \\
0 \\
0 \\
0 \\
0 \\
0 \\
0 \\
0 \\
0 \\
0 \\
0 \\
0 \\
0\end{array}$ & 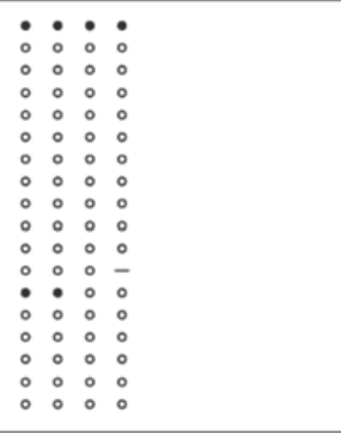 & 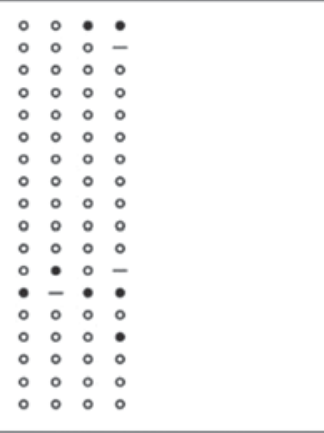 \\
\hline & & $\begin{array}{r}1 \\
3 \\
4 \\
5 \\
6 \\
8 \\
8 \\
9 \\
10 \\
11 \\
12 \\
13 \\
14 \\
15 \\
16 \\
17 \\
20 \\
21 \\
22\end{array}$ & $\begin{array}{llll}0 & 0 & 0 & c \\
0 & 0 & 0 & c \\
0 & 0 & 0 & c \\
0 & 0 & 0 & c \\
0 & 0 & 0 & c \\
0 & 0 & 0 & c \\
0 & 0 & 0 & c \\
0 & 0 & 0 & c \\
0 & 0 & 0 & c \\
0 & 0 & 0 & c \\
0 & 0 & 0 & c \\
0 & 0 & 0 & c \\
0 & 0 & 0 & c \\
0 & 0 & 0 & c \\
0 & 0 & 0 & c \\
0 & 0 & 0 & c \\
0 & 0 & 0 & c \\
0 & 0 & 0 & 0\end{array}$ & 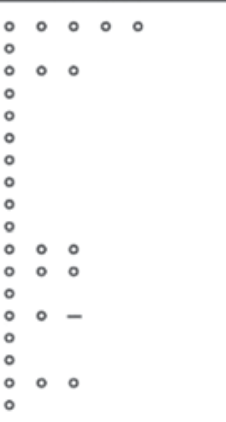 & 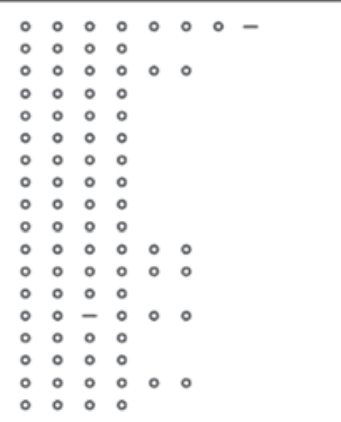 & 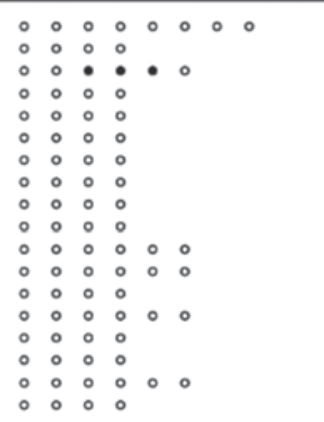 \\
\hline
\end{tabular}

Figure 1. Relative map locations of chromosome 9p markers. Approximate genetic distances (cM) were obtained from Genome Interactive Data Bases. Right panel reveals the results of loss of heterozygosity analysis at five loci of chromosome $9 p$ in 14 sporadic breast carcinomas. Three to ten different groups of cells obtained by laser capture microdissection were analyzed in each patient. Each group of cells consists of normal breast tissue (TDLU), DCIS and IDC. $\bullet$, loss of heterozygosity; o, retention of heterozygosity. DCIS, ductal carcinoma in situ; IDC, invasive ductal carcinoma. 

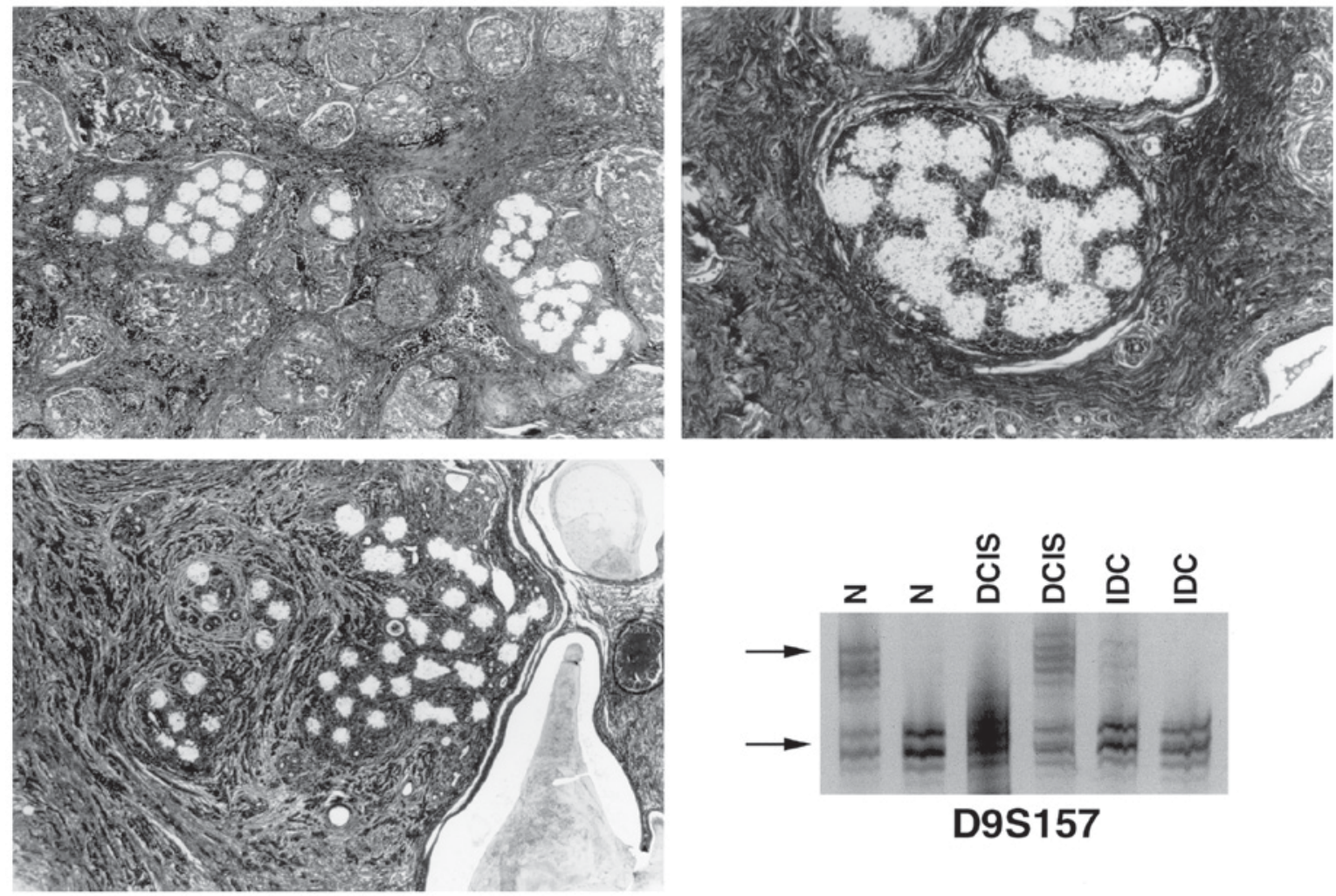

Figure 2. Representative microsatellite amplification (D9S157) relative to one patient (P1). Two foci of cells were analyzed from normal tissue surrounding tumor areas, DCIS and IDC. LOH was observed in different microdissections from IDC and DCIS and also from one foci of normal breast tissue. N, normal breast tissue; DCIS, ductal carcinoma in situ; IDC, invasive ductal carcinoma.
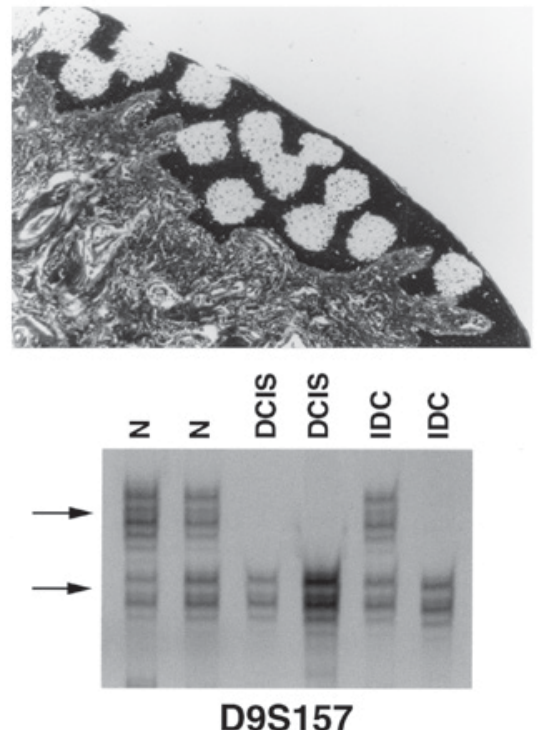

Figure 3. Genomic DNA from microdissected normal skin does not display genetic alterations. $\mathrm{N}$, normal breast tissue; DCIS, ductal carcinoma in situ; IDC, invasive ductal carcinoma.

section. The histopathological type of the carcinoma was classified according to previously described criteria (23). Control tissues consisted of phenotypically normal cells, which were obtained by LCM from: a) Type 1 lobules or terminal duct lobular units (TDLUs) (24); b) normal skin obtained from the mastectomy specimen; or c) lymph nodes free of metastases obtained from axillary dissection from the same patient. This study was approved by the Ethical Review Board (IRB 93-031) of the FCCC and informed consent was obtained from patients for use of their tissue.

$L C M$. Serial $5-\mu \mathrm{m}$ thick sections containing IDC, DCIS and normal tissue were utilized for microdissection. Areas containing IDC, DCIS or normal tissue were identified in the slide that had been stained with H\&E and coverslipped. Preferentially, areas containing microscopically homogeneous cells of each type of lesion were selected. Tissues containing areas with dense stroma, inflammatory cells, vascular or lymphatic vessels, muscle or adipose tissue were avoided. Uncoverslipped serial 5- $\mu \mathrm{m}$ sections slides were carefully matched with the respective area identified in the coverslipped stained slide for verifying the accuracy of the type of lesion selected for dissection. Tissue sections were microdissected using a PixCell laser capture microdissection apparatus (Arcturus Engineering, Mountain View, CA, USA) fitted with cap in which a transparent thermoplastic film (ethylene vinyl acetate polymer) was bonded to the underside. A cap was placed on the specific lesion or normal tissue selected for dissection under visual inspection by the operator. Then an infrared laser pulse was activated and selected cells were transferred to the undersurface of the cap, which was lifted off the tissue; the cells obtained at each one of these laser shots were termed 'a capture'. This process was repeated successively in adjacent areas of the same lesion twenty times using a 30- $\mu \mathrm{m}$ diameter laser beam. The caps containing the captured tissues were placed into a 500- $\mu 1$ microcentrifuge tube for molecular processing. Multiple foci from three to ten different areas of 


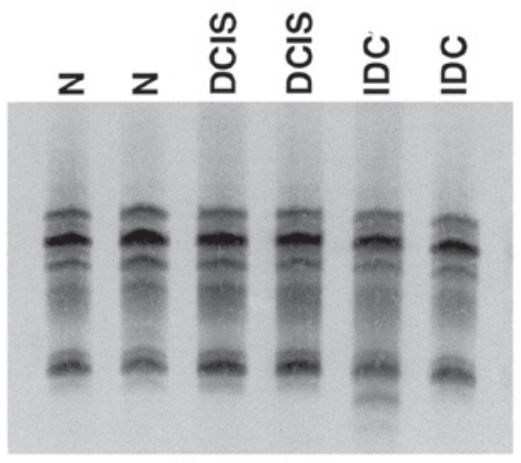

D9S270

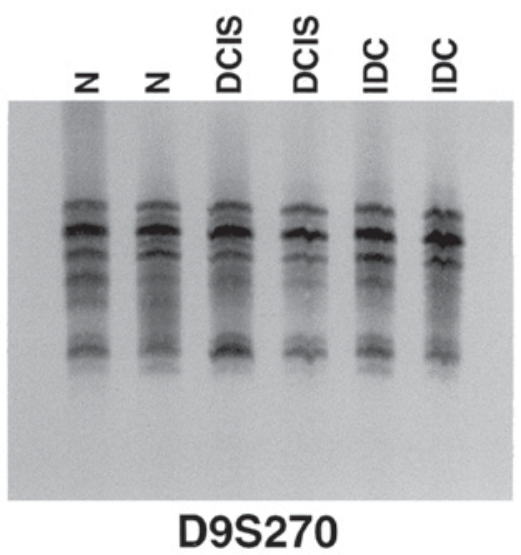

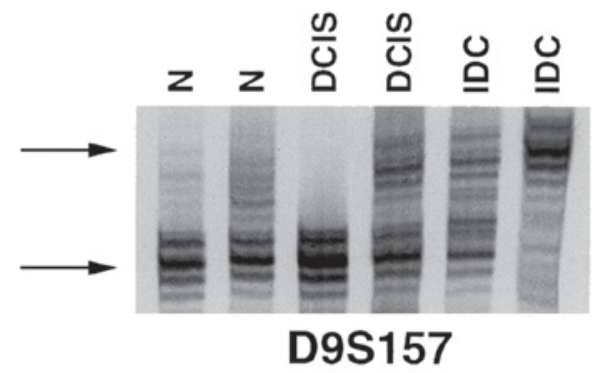

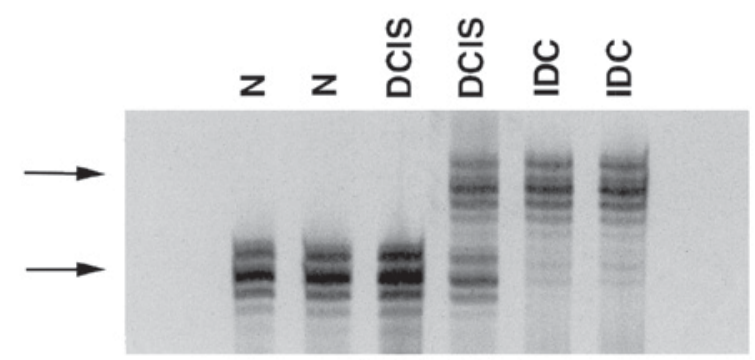

D9S157

Figure 4. Results of representative microsatellite amplifications, loss of heterozygosity and heterogeneity of the marker D9S157 is observed in different microdissections from the same patient (P3) and detected by the complete absence of one of the two alleles present in constitutional normal DNA. Black arrows indicate the positions of the major allelic bands. The same DNA samples also retain heterozygosity at D9S270. N, normal breast tissue; DCIS, ductal carcinoma in situ; IDC, invasive ductal carcinoma.

in situ cancer, invasive carcinoma and 'normal' tissue were individually microdissected and separately analyzed (Fig. 1). Finally, direct visualization of the transferred tissue by light microscopy of the capsule verified that the desired cells had been captured.

DNA extraction. DNA extraction from the selected tissues was performed following the protocol provided by PixCell II $^{\mathrm{TM}}$ (Arcturus Engineering, Inc., Mountain View, CA, USA) Selected tissues were digested for $16 \mathrm{~h}$ at $42^{\circ} \mathrm{C}$ in buffer containing: $10 \mathrm{mM}$ Tris-HCL (pH 8.8), 1 mM EDTA, $1 \%$ Tween-20 and $0.05 \%$ Proteinase K. The lysate was heated at $96^{\circ} \mathrm{C}$ for $8 \mathrm{~min}$ to inactivate Proteinase $\mathrm{K}$ and aliquots of $2 \mu \mathrm{l}$ of this lysate were used directly as templates for PCR.

Polymerase chain reaction (PCR) amplification and microsatellite analysis. Five microsatellite markers mapped to the short arm of chromosome 9 (D9S199, D9S157, D9S171, D9S265 and D9S270) were used for LOH analysis. Primers for PCR amplification were obtained from Research Genetics Inc. (Huntsville, AL, USA) and all primer sequence position of the markers, their levels of heterozygosity and distances were obtained from Genome Database version February 2000 (Research Genetics, Inc.). PCRs were carried out according to published study (25). The samples were denatured for $5 \mathrm{~min}$ at $94^{\circ} \mathrm{C}$ and loaded onto a $6 \%$ polyacrylamide gel. Electrophoresis was performed at room temperature at $1,400 \mathrm{~V}$ for $2-3 \mathrm{~h}$, depending on the length of the marker. Following electrophoresis, gels were transferred to a $3 \mathrm{~mm}$ Whatman paper, dried and autoradiographed using Kodak X-OMAT 35x43 film. Films were developed after a 48 to 72-h exposure. Autoradiograms were analyzed following the guidelines of published work (8).

\section{Results}

Invasive ductal carcinomas exhibited $\mathrm{LOH}$ for the five markers tested, and the marker at 9p22-23 (D9S157) was the most frequently identified, whereas the markers D9S171, D9S199, D9S265 and D9S270 (Fig. 1) were less frequently detected. $\mathrm{LOH}$ in the DCIS samples was found with $4 / 5$ of the markers tested. D9S157 locus was also present in the majority of the samples, followed by 9p21 (D9S171), D9S199 and D9S265. There are several reports in the literature indicating that other tumor suppressor gene(s) may reside within different $9 \mathrm{p}$ loci, namely 9p22-23 (8,15,17,26-28). Notably, phenotypically normal breast tissues that were adjacent to IDC and DCIS also exhibited LOH at D9S157 (Fig. 2) and/or D9S171. The finding that $\mathrm{LOH}$ at these loci is also present in the normal tissue adjacent to either DCIS or IDC is an indication that microsatellite instability is an early event in the pathogenesis of breast cancer, and occurs even earlier than any morphological changes are able to be identified. The present study pursued further the validation of these observations by performing LCM of normal skin and lymphocytes from lymph nodes free 
of metastatic disease from 7 of the patients and was unable to detect LOH in these other normal tissues. (Fig. 3). This data supports previous observations reported in the literature (29). It is notable that the practical implications of these observations are of major importance in the evaluation of the resected margins of conservative breast surgery.

A novel finding was that $\mathrm{LOH}$ was heterogeneous in its distribution, as it was exhibited in certain foci, but not in all of the tumor foci studied (Fig. 4), suggesting that clones of cells with varied genetic composition co-exist in the same lesion.

\section{Discussion}

The present data indicate that LOH at locus 9p22-23, (D9S157) and to a lesser degree at 9p21 (D9S171), occurs during the process of cancer initiation. More notably, clones of cells co-exist within a single tumor, indicating that they do not share a clonal origin and only those cells that have $\mathrm{LOH}$ at those loci may progress. The monoclonal origin of cancer has been suggested in the literature (30-32), and cytogenetic analyses have revealed that breast cancers are polyclonal (33-35). The use of LCM (36-38) has allowed the identification of more chromosomal aberrations than is possible using DNA isolated from tumor sections (39). By contrast to previous reports $(7,40-42)$ that sustained clonal derivation from in situ cancer, the data presented in the current study support the findings of Fujii et al (8), who reported LOH heterogeneity in multiple foci of individual DCIS lesions.

In conclusion, the present study demonstrated that more than one clone of cells may exist in a simple lesion and that genetic divergence occurs during cancer initiation and progression.

\section{Acknowledgements}

This study was supported by National Cancer Institute (grant nos. CA64896 and CA67238). Dr Margarida Dias has a fellowship from The Luso-American Foundation for Development. The authors would like to thank Dr Quivo Tahin for the critical analysis of the microsatellite DNA polymorphism data, to Dr Xiang Ao for the preparation of the slides used in laser capture microdissection and to Dr Irma H. Russo (Breast Cancer Research Laboratory, Fox Chase Cancer Center, Philadelphia PA, USA) for the critical appraisal of the manuscript.

\section{References}

1. Russo J, Yang X, Hu YF, Bove BA, Huang Y, Silva ID, Tahin Q, Wu Y, Higgy N, Zekri A and Russo IH: Biological and molecular basis of human breast cancer. Front Biosci 3: D944-D960, 1998

2. Werner M, Mattis A, Aubele M, Cummings M, Zitzelsberger H, Hutzler P and Höfler H: 20q13.2 amplification in intraductal hyperplasia adjacent to in situ and invasive ductal carcinoma of the breast. Virchows Arch 435: 469-472, 1999.

3. Harris JR and Hellman S: Natural history of breast cancer. In: Diseases of the Breast. Harris JR, Lippman ME, Morrow M and Hellman S (eds). Lippincott Raven, Philadelphia, PA, pp375-391, 1996.

4. Lakhani SR: The transition from hyperplasia to invasive carcinoma of the breast. J Pathol 187: 272-278, 1999.

5. Werner M, Mattis A, Aubele M, Cummings M, Zitzelsberger HH, Hhutzler P and Höfler H: 20q13.2 amplification in intraductal hyperplasia adjacent to in situ and invasive ductal carcinoma of the breast. Virchows Arch 435: 469-472, 1999.
6. Eiriksdottir G, Sigurdsson A, Jonasson JG, Agnarsson BA, Sigurdsson H, Gudmundsson J, Bergthorsson JT, Barkardottir RB, Egilsson V and Ingvarsson S: Loss of heterozygosity on chromosome 9 in human breast cancer: Association with clinical variables and genetic changes at other chromosome regions. Int J Cancer 64: 378-382, 1995.

7. Kuukasjärvi T, Karhu R, Tanner M, Kähkönen M, Schäffer A, Nupponen N, Pennanen S, Kallioniemi A, Kallioniemi OP and Isola J: Genetic heterogeneity and clonal evolution underlying development of asynchronous metastasis in human breast cancer. Cancer Res 57: 1597-1604, 1997.

8. Fujii H, Marsh C, Cairns P, Sidransky D and Gabrielson E: Genetic divergence in the clonal evolution of breast cancer. Cancer Res 56: 1493-1497, 1996.

9. Czerniak B, Chatuverdi V, Li L, Hodges S, Johnston D, Ro JY, Luthra R, Logothetis C, Von Eschenbach AC, Grossman HB, et al: Superimposed histologic and genetic mapping of chromosome 9 in progression of human urinary bladder neoplasia: Implications for a genetic model of multistep carcinogenesis and early detection of urinary bladder cancer. Oncogene 18: 1185-1196, 1999.

10. Campbell IG, Foulkes WD, Beynon G, Davis M and Englefield P: $\mathrm{LOH}$ and mutation analysis of CDKN2 in primary human ovarian cancers. Int J Cancer 63: 222-225, 1995.

11. Nakanishi H, Wang XL, Imai FL, Kato J, Shiiba M, Myia T, Imai $Y$ and Tanzawa H: Localization of a novel tumor suppressor gene loci on chromosome 9p21-22 in oral cancer. Anticancer Res 19: 29-34, 1999.

12. Murphy DS, Hoare SF, Going JJ, Mallon EE, George WD, Kaye SB, Brown R, Black DM and Keith WN: Characterization of extensive genetic alterations in ductal carcinoma in situ by fluorescence in situ hybridization and molecular analysis. J Natl Cancer Inst 87: 1694-1704, 1995.

13. Berns EM, Klijn JG, Smid M, van Staveren IL, Gruis NA and Foekens JA: Infrequent CDKN2 (MTS1/p16) gene alterations in human primary breast cancer. Br J Cancer 72: 964-967, 1995.

14. Quesnel B, Fenaux P, Philippe N, Fournier J, Bonneterre J, Preudhomme C and Peyrat JP: Analysis of p16 gene deletion and point mutation in breast carcinoma. Br J Cancer 72: 351-353, 1995.

15. Xu L, Sgroi D, Sterner CJ, Beauchamp RL, Pinney DM, Keel S, Ueki K, Rutter JL, Buckler AJ and Louis DN: Mutational analysis of CDKN2 (MTS1/p16INK4) in human breast carcinomas. Cancer Res 54: 5262-5264, 1994.

16. Brenner AJ and Aldaz M: Chromosome 9p allelic loss and p16/CDK N2 in breast cancer and evidence of p16 inactivation in immortal breast epithelial cells. Cancer Res 55: 2892-2895, 1995.

17. An HX, Niederacher D, Picard F, van Roeyen C, Bender HG and Beckmann MW: Frequent allele loss on 9p21-22 defines a smallest common region in the vicinity of the CDKN2 gene in sporadic breast cancer. Genes Chromosomes Cancer 17: 14-20, 1996.

18. Minobe K, Onda M, Iida A, Kasumi F, Sakamoto G, Nakamura Y and Emi M: Allelic loss on chromosome $9 \mathrm{q}$ is associated with lymph node metastasis of primary breast cancer. Jpn J Cancer Res 89: 916-922, 1998.

19. Cairns P, Polascik TJ, Eby Y, Tokino K, Califano J, Merlo A, Mao L, Heath J, Jenkins R, Westra W, et al: Frequency of homozygous deletion at p16/CDKN2 in primary human tumors. Nat Genet 11: 210-212, 1995.

20. Dutrilaux B, Gerbault-Senreau M and Zafrani B: Characterization of chromosomal abnormalities in human breast cancer. A comparison of 30 paradiploid cases with few chromosome changes. Cancer Genet Cytogenet 49: 203-217, 1990.

21. Emmert-Buck MR, Bonner RF, Smith PD, Chuaqui RF, Zhuang Z, Goldstein SR, Weiss RA and Liotta LA: Laser capture microdissection. Science 274: 998-1001, 1996.

22. Bonner RF, Emmert-Buck M, Cole K, Pohida T, Chuaqui R, Goldstein S and Liotta LA: Laser capture microdissection: Molecular analysis of tissue. Science 278: 1481-1483, 1997.

23. Simone NL, Bonner RF, Gillespie JW, Emmert-Buck MR and Liotta LA: Laser capture microdissection: Opening the microscopic frontier to molecular analysis. Trends Genet 14: 272-276, 1998.

24. Russo J and Russo IH: The pathology of breast cancer: Staging and prognostic indicators. J Am Med Womens Assoc (1972) 47: 181-187, 1992.

25. Russo J, Gusterson BA, Rogers AE, Russo IH, Wellings SR and van Zwieten MJ: Comparative study of human and rat mammary tumorigenesis. Lab Invest 62: 244-278, 1990. 
26. Kellogg DE, Rybalkin I, Chen S, Mukhamedova N, Vlasik T, Siebert PD and Chenchik A: TaqStart Antibody: 'hot start' PCR facilitated by a neutralizing monoclonal antibody directed against Taq DNA polymerase. Biotechniques 16: 1134-1137, 1994.

27. Wu Y, Barnabas N, Russo IH, Yang X and Russo J: Microsatellite instability and loss of heterozygosity in chromosomes 9 and 16 in human breast epithelial cells transformed by chemical carcinogens. Carcinogenesis 18: 1069-1074, 1997.

28. Muzeau F, Flejou JF, Thomas G and Hamelin R: Loss of heterozygosity on chromosome 9 and p16 (MTS1, CDKN2) gene mutations in esophageal cancers. Int J Cancer 72: 27-30, 1997.

29. Morita R, Fujimoto A, Hatta N, Takehara $K$ and Takata M: Comparison of genetic profiles between primary melanomas and their metastases reveals genetic alterations and clonal evolution during progression. J Invest Dermatol 111: 919-924, 1998.

30. Deng G, Lu Y, Zlotikov G, Thor AD and Smith HS: Loss of heterozygosity in normal tissue adjacent to breast carcinomas. Science 274: 2057-2059, 1996

31. Nowell PC: The clonal evolution of tumor cell populations. Science 194: 23-28, 1976

32. Fialkow PJ: Clonal origin of human tumors. Biochem Biophys Acta 458: 283-321, 1976.

33. Noguchi S, Motomura K, Inaji H, Imaoka S and Koyamma H: Clonal analysis of human breast cancer by means of the polymerase chain reaction. Cancer Res 52: 6594-6597, 1992.

34. Teixeira MR, Pandis N, Bardi G, Andersen JA, Mitelman F and Heim S: Clonal heterogeneity in breast cancer: karyotypic comparisons of multiple intra- and extra-tumorous samples from 3 patients. Int J Cancer 63: 63-68, 1995.

35. Teixeira MR, Pandis N, Bardi G, Andersen JA and Heim S: Karyotypic comparisons of multiple tumors and macroscopically normal surrounding tissue samples from patients with breast cancer. Cancer Res 56: 855-859, 1996.
36. Pandis N, Jin Y, Gorunova L, Petersson C, Bardi G, Idvall I, Johansson B, Ingvar C, Mandahl N and Mitelman F: Chromosome analysis of 97 primary breast carcinomas: Identification of eight karyotypic subgroups. Genes Chromosomes Cancer 12: 173-185, 1995.

37. Böni R, Matt D, Voetmeyer A, Burg G and Zhuang Z: Chromosomal allele loss in primary melanoma is heterogeneous and correlates with proliferation. J Invest Dermat 110: 215-217, 1998.

38. Ornstein DK, Englert C, Gillespie JW, Paweletz CP, Linehan WM, Emmert-Buck MR and Petricoin EF III: Characterization of intracellular prostate-specific antigen from laser capture microdissected benign and malignant prostatic epithelium. Clin Cancer Res 6: 353-356, 2000.

39. Milchgrub S, Wistuba II, Kim BK, Rutherford C, Urban J, Cruz PD Jr and Gazdar AF: Molecular identification of metastatic cancer to the skin using laser capture microdissection: A case report. Cancer 88: 749-754, 2000

40. Aubele M, Mattis A, Zitzelsberger H, Walch A, Kremer M, Hutzler P, Höfler $\mathrm{H}$ and Werner M: Intratumoral heterogeneity in breast carcinoma revealed by laser-microdissection and comparative genomic hybridization. Cancer Genet Cytogenet 110: 94-102, 1999

41. Zhuang Z, Merino MJ, Chuaqui R, Liotta LA and Emmert-Buck MR: Identical allelic loss on chromosome 11q13 in microdissected in situ and invasive human breast cancer. Cancer Res 55: 467-471, 1995.

42. Radford DM, Phillips NJ, Fair KL, Ritter JH, Holt M and Donis-Keller H: Allelic loss and the progression of breast cancer. Cancer Res 55: 5180-5183, 1995. 